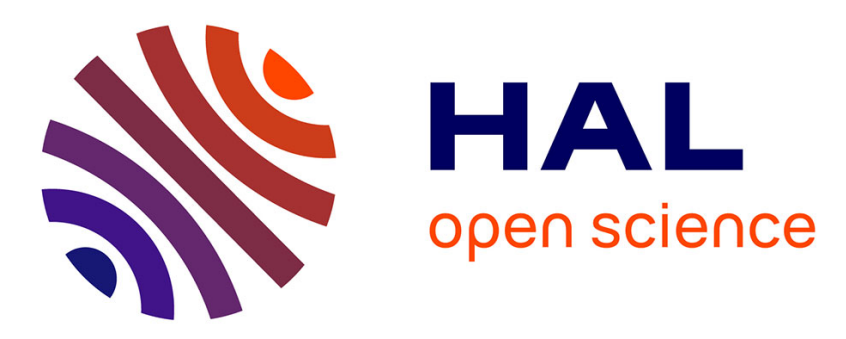

\title{
Immunolocalization of meiotic proteins in Brassicaceae: method 1
}

\author{
Liudmila Chelysheva, Laurie Grandont, Mathilde Grelon
}

\section{To cite this version:}

Liudmila Chelysheva, Laurie Grandont, Mathilde Grelon. Immunolocalization of meiotic proteins in Brassicaceae: method 1. Plant Meiosis, Methods and Protocols, 990, Springer, 2013, Methods in Molecular Biology, 1940-6029. 10.1007/978-1-62703-333-6_9 . hal-01204089

\section{HAL Id: hal-01204089 \\ https://hal.science/hal-01204089}

Submitted on 6 Jun 2020

HAL is a multi-disciplinary open access archive for the deposit and dissemination of scientific research documents, whether they are published or not. The documents may come from teaching and research institutions in France or abroad, or from public or private research centers.
L'archive ouverte pluridisciplinaire HAL, est destinée au dépôt et à la diffusion de documents scientifiques de niveau recherche, publiés ou non, émanant des établissements d'enseignement et de recherche français ou étrangers, des laboratoires publics ou privés. 


\title{
Immunolocalization of Meiotic Proteins in Brassicaceae: Method 1
}

\author{
Liudmila A. Chelysheva, Laurie Grandont, and Mathilde Grelon
}

\begin{abstract}
Plant meiosis studies have enjoyed a fantastic boom in recent years with the use of Arabidopsis thaliana as an important model species for developmental studies because of its small genome, short life cycle, and large mutant collections. Unlike other eukaryotic models, plant meiosis does not display strict checkpoints and rarely commits to apoptotic processes, which makes it possible to investigate the whole meiotic process (spanning from premeiotic interphase to spore formation) in knockout mutants. In this chapter we describe a protocol for immunolabelling Arabidopsis and Brassica meiotic proteins on robustly spread chromosomes. This protocol allows the detection of a large range of proteins on well-preserved chromosomes and throughout the entire meiotic process.
\end{abstract}

Keywords Arabidopsis, Brassica napus, Cytogenetics, Chromosome, Meiosis, Immunolabelling

\section{Introduction}

Significant progress in the study of Arabidopsis meiosis has been made these last years. With the development of cytogenetic techniques (1-3) chromosome organization and behavior could be analyzed during meiotic progression in wild type and various meiotic mutants. These first protocols were based on an acetic acid cell-spreading of flower buds fixed in Carnoy's fixative. Then, Armstrong and colleagues (4) developed techniques for immunolabelling meiotic proteins, which allowed the detailed analysis of spatial and temporal expression of different proteins throughout prophase of meiosis I. This commonly used protocol requires fresh material on which lipsol or Triton X-100 spreading and paraformaldehyde fixation are applied (see Chapter 10). Unfortunately this method of immunolabelling has limitations: often poor resolution because of mild spreading efficiency of lipsol, loss of stages beyond pachytene, and poorly preserved chromosome organization. To overcome these limitations, we developed a technique that allows 
immunolocalization of proteins using Carnoy's fixative and acetic acid chromosome spreads (5). This method combines a strong fixation to preserve chromosome structure, acetic acid spreading to remove the cytoplasm, and microwave treatment to increase the accessibility of protein to antibodies.

\section{Materials}

\subsection{Plants}

\subsection{Chromosome} Preparation
1. Arabidopsis thaliana plants grown in greenhouse, photoperiod $16 \mathrm{~h}$ day and $8 \mathrm{~h}$ night; temperature $20^{\circ} \mathrm{C}$ day and night; humidity $70 \%$ (see Note 1 ).

2. Brassica napus plants grown in greenhouse, photoperiod $16 \mathrm{~h}$ per day and $8 \mathrm{~h}$ per night; temperature $22^{\circ} \mathrm{C}$ day and $18^{\circ} \mathrm{C}$ night; humidity $65 \%$ (see Note 1 ).

1. Carnoy's fixative: mix absolute ethanol (3 volumes) and glacial acetic acid (1 volume).

2. Citrate buffer $\mathrm{pH}$ 4.5: $10 \mathrm{mM}$ sodium citrate/citric acid, $\mathrm{pH}$ 4.5. Weigh $2.94 \mathrm{~g}$ of tri-sodium citrate and transfer to a graduated glass beaker. Add distilled water up to $800 \mathrm{ml}$. Prepare $100 \mathrm{ml}$ of $100 \mathrm{mM}$ citric acid (2.1 $\mathrm{g}$ in $100 \mathrm{ml}$ of distilled water). Progressively add citric acid solution to the $800 \mathrm{ml}$ of tri-sodium citrate solution until $\mathrm{pH} 4.5$. Top up to 11 with distilled water. Sterilize and make $40 \mathrm{ml}$ aliquots. Store at $-20^{\circ} \mathrm{C}$.

3. Citrate buffer $\mathrm{pH}$ 6.0: $10 \mathrm{mM}$ sodium citrate/citric acid, $\mathrm{pH}$ 6.0. Prepare $0.1 \mathrm{M}$ citric acid (21.01 g in 11 of distilled water). Prepare $0.1 \mathrm{M}$ tri-sodium citrate $(29.41 \mathrm{~g}$ in 11 of distilled water). Add $9 \mathrm{ml}$ of $0.1 \mathrm{M}$ citric acid solution to $41 \mathrm{ml}$ of $0.1 \mathrm{M}$ tri-sodium citrate solution. Top up to $500 \mathrm{ml}$ with distilled water. Store at $4^{\circ} \mathrm{C}$ (see Note 2$)$.

4. Digestion enzyme mixture: $0.3 \%(\mathrm{w} / \mathrm{v})$ cellulase Onozuka R-10 (Yakult Pharmaceutical Industry Co., Ltd., Tokyo, Japan), $0.3 \%$ (w/v) pectolyase Y-23 (MP Biomedicals, Santa Ana, CA, USA), $0.3 \%$ (w/v) cytohelicase (Sigma Aldrich, St. Louis, MO, USA) in $10 \mathrm{mM}$ citrate buffer $\mathrm{pH} 4.5$. Weigh $1.5 \mathrm{~g}$ of each enzyme and dissolve in $500 \mathrm{ml}$ of sterilized $10 \mathrm{mM}$ citrate buffer $\mathrm{pH} 4.5$. Aliquot by $40 \mathrm{ml}$ and store at $-20^{\circ} \mathrm{C}$.

5. $60 \%$ acetic acid.

6. Embryo dishes.

7. Stereomicroscope equipped with eyepiece micrometer disk.

8. Standard microscope slides (Knittel Glaser, Braunschweig, Germany) cleaned with $70 \%$ ethanol.

9. Dissection needles, a hook (curved dissection needle), and a fine forceps. 
10. Moist chamber for enzyme digestion. A hermetic plastic box $180 \times 120 \times 75 \mathrm{~mm}^{3}$ with a wet paper on bottom.

11. Glass Pasteur pipette.

12. Heating block $\left(45^{\circ} \mathrm{C}\right)$.

13. Incubator $\left(37^{\circ} \mathrm{C}\right)$.

14. Glass and plastic Hellendahl jars (VWR, Radnor, PA, USA).

15. Microwave oven.

1. $1 \times$ PBS: $10 \mathrm{mM}$ sodium phosphate, $\mathrm{pH} 7.0,143 \mathrm{mM} \mathrm{NaCl}$.

2. PBST: $0.1 \%$ Triton-X 100 in $1 \times$ PBS.

3. PBST-BSA: $1 \%$ BSA in $1 \times$ PBST.

4. Secondary antibodies conjugated to Alexa (Invitrogen, Carlsbad, CA, USA) or DyLight (Thermo Fisher Scientific, Waltham, Massachusetts, USA).

5. DAPI solution: $2 \mu \mathrm{g} / \mathrm{mL}$ DAPI (4',6-diamidino-2phenylindole) in Vectashield (Vector Labs, Burlingame, CA, USA).

6. Laboratory film Parafilm "M" (Sigma Aldrich, St. Louis, MO, USA).

7. Coverslips $24 \times 32 \mathrm{~mm}$.

8. Moist chamber: a hermetic container (e.g., square Petri dish) with wet paper on the bottom and two rails in order to keep microscopic slides horizontally.

9. Incubator $\left(37^{\circ} \mathrm{C}\right)$.

10. Fluorescence microscope equipped with a high resolution CCD camera.

\section{Methods}

\subsection{Chromosome Preparation}

1. Fix the inflorescences in freshly prepared Carnoy's fixative for $3 \times 60 \mathrm{~min}$ and keep them in fixative for at least 3 days at $4^{\circ} \mathrm{C}$ (see Note 3). Fixed material can be stored in fixative at $4^{\circ} \mathrm{C}$ or $-20^{\circ} \mathrm{C}$ for several months.

2. Rinse the fixed inflorescences once with distilled water in an embryo dish.

3. Replace the water with citrate buffer $\mathrm{pH} 4.5$ and wash $2 \times 5 \mathrm{~min}$.

4. Replace the citrate buffer with the digestion enzyme mixture. Incubate for $3 \mathrm{~h}$ ( $3.5 \mathrm{~h}$ for Brassica inflorescences) in a moist chamber at $37^{\circ} \mathrm{C}$. Ensure that all material is submerged in the digestion mixture.

5. Replace the digestion mix with water and from now on keep material on ice. Digested inflorescences can be stored at $4^{\circ} \mathrm{C}$ overnight. 
6. Take a single inflorescence in a drop of distilled water on a slide and select three flower buds of appropriate stage (see Notes 4 and 5). Extract anthers and place them in $4 \mu \mathrm{l}$ of water on an ethanol-cleaned slide. For Brassica samples, prepare each slide with a single anther.

7. Crush anthers with a hook until a fine suspension has formed (see Note 6).

8. Add $10 \mu \mathrm{l}$ of $60 \%$ acetic acid to the suspension on the slide. Place the slide on the heating block for $2 \mathrm{~min}$ at $45^{\circ} \mathrm{C}$. Add another $10 \mu \mathrm{l}$ of $60 \%$ acetic acid after the first minute of heating. For Brassica, add $20 \mu \mathrm{l}$ of $60 \%$ acetic acid on the slide and place it for $5 \mathrm{~min}$ at $45^{\circ} \mathrm{C}$. Add $10 \mu \mathrm{l}$ of $60 \%$ acetic acid after 2 min of heating.

9. During step 8 , stir the drop with the hook without stopping (see Note 7) in order to remove as much cytoplasm as possible.

10. Fix the cells on slides first by pipetting cold Carnoy's fixative around the drop of the cleared cell suspension. Then, at the end, add the remaining Carnoy's by pipetting directly onto the top of the suspension. Hold the slide vertically to get rid of the liquid. Air-dry the preparation.

11. Put up to eight slides in $10 \mathrm{mM}$ citrate buffer $\mathrm{pH} 6$ in a plastic Hellendahl jar and microwave them for $45 \mathrm{~s}$ at $850 \mathrm{~W}$.

12. Transfer the slides immediately to PBS-T in a glass Hellendahl jar. Incubate for $5 \mathrm{~min}$ at RT.

1. Dilute the primary antibodies to the appropriate concentration in PBST-BSA and centrifuge them $3 \mathrm{~min}$ at $10,000 \times \mathrm{g}$.

2. Use $50 \mu \mathrm{l}$ of the antibody working solution per slide, cover with $24 \times 40 \mathrm{~mm}$ pieces of parafilm.

3. Incubate at $4^{\circ} \mathrm{C}$ for $24-48 \mathrm{~h}$ in a moist chamber.

4. Rinse the slides in PBST, $3 \times 15$ min at RT.

5. Mix the secondary antibodies in PBST-BSA at a dilution of $1: 100$ to $1: 2,000$ (see Note 8).

6. Use $50 \mu \mathrm{l}$ of solution per slide, cover with $24 \times 40 \mathrm{~mm}$ pieces of parafilm and incubate at $37^{\circ} \mathrm{C}$ for $\mathrm{l} \mathrm{h}$ in a dark moist chamber.

7. Rinse the slides in PBST, $3 \times 10$ min at RT.

8. Put $15 \mu$ l of DAPI solution per slide and cover with a $24 \times 32$ coverslip.

9. Observe the slides under a fluorescent microscope using the appropriate filters (see Note 9) (Figs. 1, 2, and 3). 


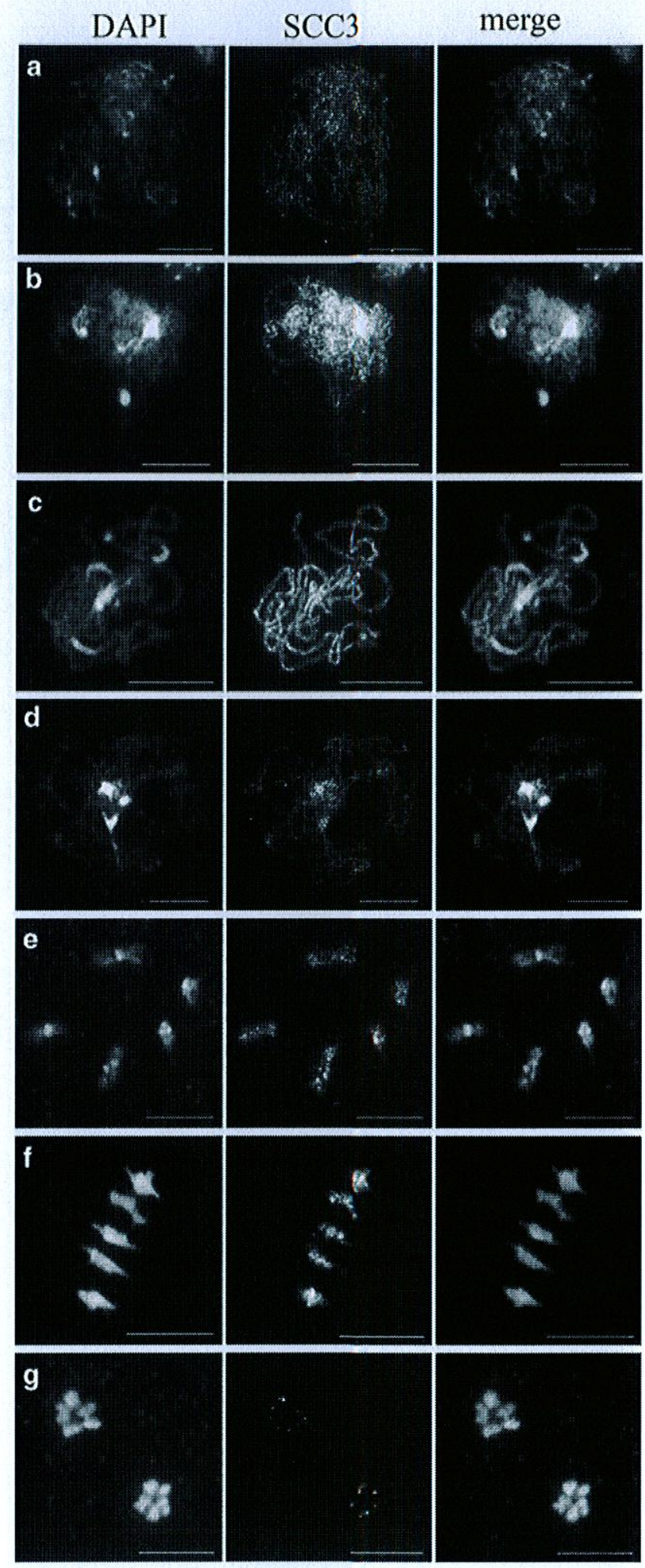

Fig. 1 Immunolocalization of AtSCC3 on Arabidopsis pollen mother cells. The cohesin AtSCC3 (6) was immunolocalized on Arabidopsis pollen mother cells chromosomes after acetic acid spreading. For each cell DAPI, AtSCC3 and merged signals are shown. (a) Leptotene. (b) Zygotene. (c) Pachytene. (d) Diplotene. (e) Diakinesis. (f) Metaphase I. (g) Telophase 1. Bar: $10 \mu \mathrm{m}$ 
DAPI

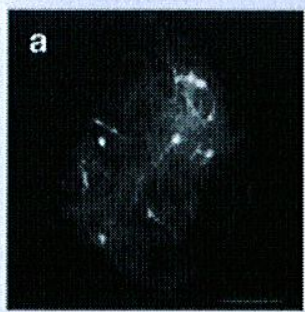

b
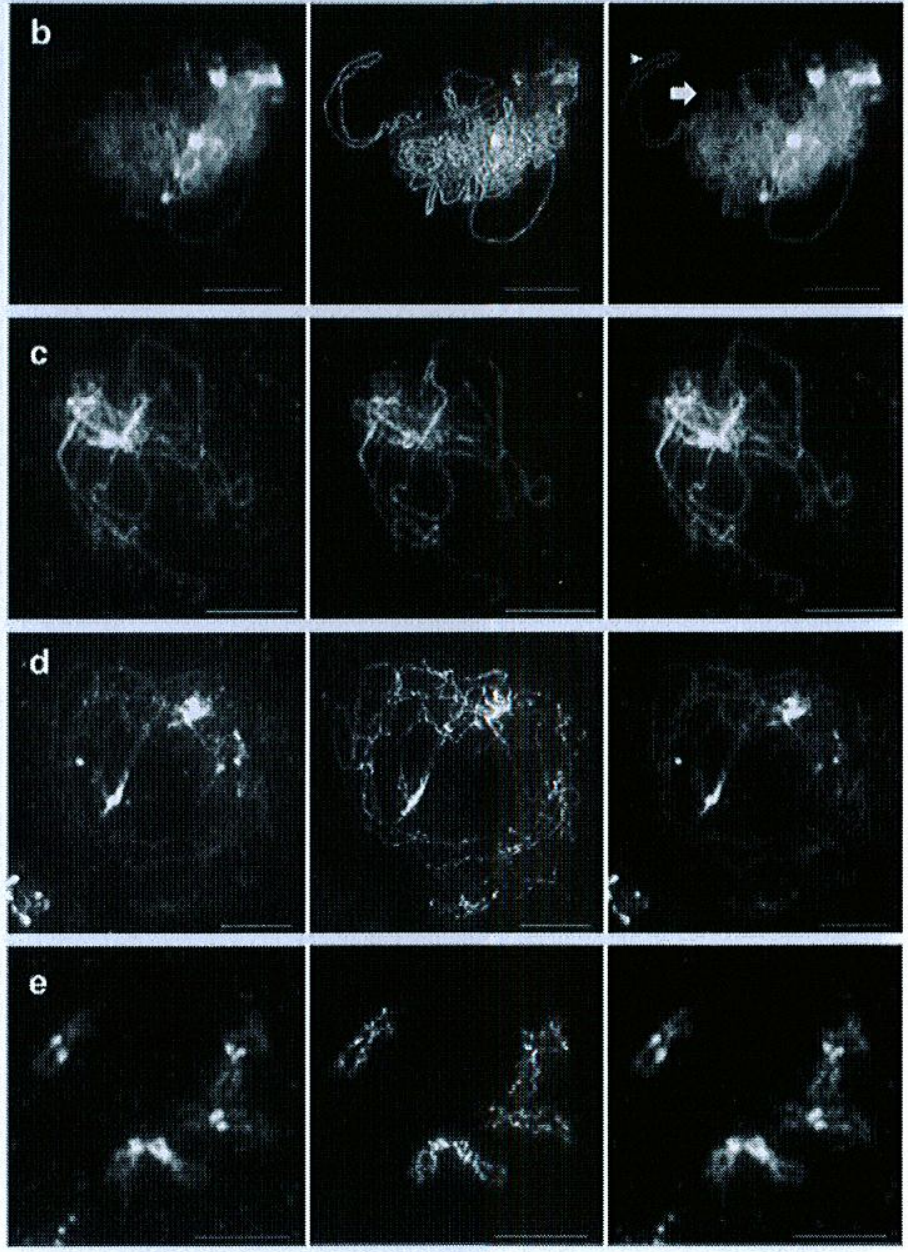

Fig. 2 Immunolocalization of ASY1 on Arabidopsis pollen mother cells. The axisassociated protein ASY1 was immunolocalized on Arabidopsis pollen mother cells chromosomes after acetic acid spreading (4). For each cell DAPI, ASY1 and merged signals are shown. (a) A leptotene cell showing numerous dotted lines corresponding to the ASY1 signal. (b) A zygotene cell showing continuous ASY1 signals along chromosomal axes; the arrowhead indicates a bright ASY1-labelled unsynapsed region, while the arrow indicates a synapsed region, with faint ASY1 signal. (c) Pachytene. (d) Diplotene. (e) Diakinesis. Bar, $10 \mu \mathrm{m}$ 


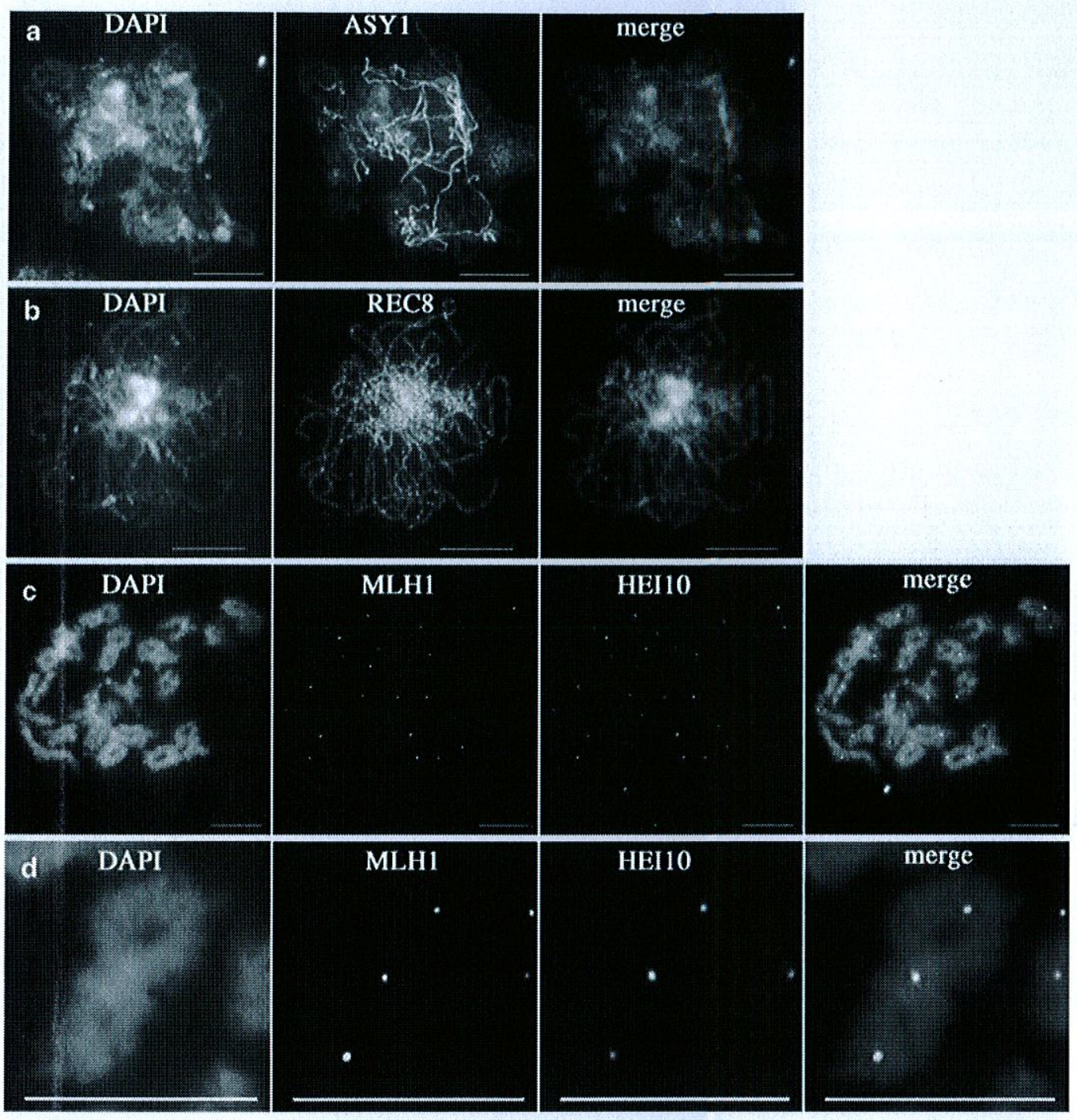

Fig. 3 Immunolocalization of AtASY1, AtREC8, AtMLH1, and AtHEl10 on Brassica napus pollen mother cells. (a) Immunolocalization of the axis protein ASY1 on Brassica napus pollen mother cells chromosomes at zygotene using an antibody directed against the Arabidopsis thaliana ASY1 protein (4). DAPI, ASY1 and merged signals are shown. (b) Immunolocalization of the meiotic cohesin REC8 on Brassica napus pollen mother cells chromosomes at pachytene using an antibody directed against the Arabidopsis thaliana REC8 protein (7). DAPI, REC8 and merged signals are shown. (c) Co-immunolocalization of MLH1 and HEl10 proteins on Brassica napus pollen mother cells chromosomes at diakinesis. Anti-MLH1 and anti-HEl10 sera were developed against the Arabidopsis thaliana proteins (5). (d) A zoom on one bivalent from (c). For (c) and (d), DAPI, MLH1, HEl10, and merged signals are shown. Bar, $10 \mu \mathrm{m}$ 


\section{Notes}

1. Good and reproducible growth conditions are particularly important because inappropriate growth conditions can considerably affect the dynamics of meiotic progression. Furthermore, it can be difficult to recover enough material from unhealthy plants.

2. We found that the utilization of commercial citrate buffer $\mathrm{pH} 6.0$ (Diapath S.p.A., Martinengo, Italy) gives very good results.

3. A fixation shorter then 3 days can be insufficient to make all proteins available to immunodetection. In consequence, meiocytes extracted from partially fixed buds will show only partial chromosome immunostaining.

4. In Arabidopsis, pollen mother cells develop synchronously, which make it possible to relate the meiotic progression to the bud size. Nevertheless, this correspondence is dependent on the genotype (variability among the ecotypes or between wild type and mutants) and growth conditions. Therefore, it is very important to define it for your own material. Roughly, $0.4 \mathrm{~mm}$ buds contain prophase I pollen mother cells, $0.5 \mathrm{~mm}$ buds contain metaphase I meiocytes, $0.6 \mathrm{~mm}$ buds - metaphase II to telophase II, and $0.75 \mathrm{~mm}$ buds tetrads and microspores in Columbia- 0 .

5. In Brassica, bud size is poorly correlated with pollen mother cell development stages but development stages are homogenous among the various anthers of a single bud. Therefore, it is possible to select appropriate buds after acetocarmine staining of one anther per bud. To do it, extract one anther from a fixed bud and place it on a slide. Add $30 \mu \mathrm{l}$ of acetocarmine and crush the anther. Cover with a coverslip $24 \times 32 \mathrm{~mm}$. Place the slide on the heating block for $8 \mathrm{~min}$ at $45^{\circ} \mathrm{C}$. Observe the slides under a bright field microscope.

6. It is very important to make a fine cell suspension in order to treat all cells efficiently with acetic acid and to get rid of most of the cytoplasm. However, it is also very important to prevent drop evaporation that would make meiocytes stick to the slide and dry, rendering them unavailable to the subsequent acetic acid treatment. In this case, many faintly stained meiocytes will be observed, surrounded by cytoplasm.

7. To amplify acetic acid treatment, the droplet with cells should be stirred vigorously with a hook without touching the glass surface.

8. The appropriate dilution for secondary antibodies should be determined experimentally and can sometimes be more diluted than suggested by the supplier.

9. The fluorescence signal of far-red fluorochromes (e.g., Alexa647, DyLight-640) can be visualized only by image acquisition. 


\section{Acknowledgments}

We thank Wayne Crismani for constructive reading of the manuscript, and C. Franklin and C. Makaroff for providing ASYI and REC8 antibodies, respectively.

\section{References}

1. Fransz P, Arnstrong $S$, Alonso-Blanco C, Fischer TC, Torres-Ruiz RA, Jones GH (1998) Cytogenetics for the model system Arabidopsis thaliana. Plant J 13:867-876

2. Heslop-Harrison IS (1998) Cytogenetic analysis of Arabidopsis. Methods Mol Biol 82:119-127

3. Ross KJ, Fransz P, Jones GH (1996) A light microscopic atlas of meiosis in Arabidopsis thaliana. Chromosome Res 4:507-516

4. Armstrong SI, Caryl AP, Jones GH, Franklin FCH (2002) Asyl, a protein required for meiotic chromosome synapsis, localizes to axis-associated chromatin in Arabidopsis and Brassica. J Cell Sci 115:3645-3655

5. Chelysheva L, Grandont L, Vriclynck N, le Guin S, Mercier R, Grelon M (2010) An easy proto- col for studying chromatin and recombination protein dynamics during Arabidopsis thaliana meiosis: inmunodetection of cohesins, histones and MLHl. Cytogenet Genome Res 129: 143-153

6. Chelysheva L, Diallo S, Vezon D, Gendrot G, Vrielynck N, Belcram K et al (2005) AtREC8 and AtSCC3 are essential to the monopolar orientation of the kinetochores during meiosis. J Cell Sci 118:462 I-4632

7. Cai X, Dong F, Edelmann RE, Makaroff CA (2003) The Arabidopsis SYNl cohesin protein is required for sister chromatid arm cohesion and homologous chromosome pairing. J Cell Sci 1 16:2999-3007 